\begin{tabular}{ll}
\hline ISSN: 1410-8917 & Jurnal Kimia Sains dan Aplikasi 24 (5) (2021): 177-184 \\
Jurnal Kimia & Jurnal Kimia Sains dan Aplikasi \\
Aplikasi & Journal of Scientific and Applied Chemistry \\
\hline
\end{tabular}

\title{
Development of a Fast Simultaneous Analysis Method for Determination of Middle Rare-Earth Elements in Monazite Samples
}

\author{
Heru Agung Saputra ${ }^{a, 1}$, Anni Anggraeni ${ }^{a, 2, *}$, Abdul Mutalib ${ }^{a, 3}$, Husein Hernandi Bahti ${ }^{a, 4}$ \\ ${ }^{\text {a }}$ Department of Chemistry, Universitas Padjadjaran, Jatinangor, Sumedang 45363, Indonesia \\ Author's email: (1) heru14001@mail.unpad.ac.id; (2) anni.anggraeni@unpad.ac.id; (3) mutalib@unpad.ac.id; \\ (4) husein.bahti@unpad.ac.id
}

https://doi.org/10.14710/jksa.24.5.177-184

\begin{tabular}{l} 
Article Info \\
\hline Article history: \\
Received: $22^{\text {nd }}$ July 2020 \\
Revised: $9^{\text {th }}$ June 2021 \\
Accepted: $27^{\text {th }}$ July 2021 \\
Online: $31^{\text {st }}$ July 2021 \\
\hline
\end{tabular}

\section{Keywords:}

monazite; middle rare earth elements; multivariate analysis; ultraviolet-visible spectroscopic

\begin{abstract}
Rare earth elements are a set of seventeen metallic elements, which is an essential part of many high-tech devices. Hence, analysis and/or separation of the rare earth elements from their mineral become crucial. A novel analysis method combining ultraviolet-visible spectroscopic and multivariate analysis was developed to determine middle rare earth elements quickly and simultaneously. The data collected from ultraviolet-visible spectroscopic were analyzed by multivariate analysis. The results showed that the developed method has good accuracy and precision with a detection limit of $1.375( \pm 0.012)$, $0.332( \pm 0.004), 42.117( \pm 0.200), 1.767( \pm 0.011)$, and $0.576( \pm 0.002) \mathrm{ppm}$, respectively for samarium, europium, gadolinium, terbium, and dysprosium. The interference effect of ammonium iron(II) sulfate hexahydrate, manganese(III) sulfate hydrate, calcium carbonate, sodium carbonate, and lead(II) nitrate were examined. The reliability of the proposed method was evaluated using monazite samples. Conclusively, the developed method was successfully applied to determine the middle rare earth elements in monazite samples.
\end{abstract}

\section{Introduction}

A rare-earth element (REE) is one of a set of seventeen chemical elements in the periodic table, specifically the fifteen lanthanides: lanthanum (La), cerium (Ce), praseodymium (Pr), neodymium (Nd), promethium $(\mathrm{Pm})$, samarium $(\mathrm{Sm})$, europium $(\mathrm{Eu})$, gadolinium (Gd), terbium (Tb), dysprosium (Dy), holmium (Ho), erbium (Er), thulium (Tm) ytterbium $(\mathrm{Yb})$, and lutetium (Lu); as well as scandium (Sc) and yttrium (Y) [1]. Except for La, the lanthanide series comprises unique elements with ground state electronic configurations with at least one electron in the $4 \mathrm{f}$ electronic orbital. Scandium and Yttrium, a Group IIIB transition metal, are typically included with the REEs. They occur with the rare-earth metals in natural minerals and have similar physical and chemical properties [2, 3, 4]. The initial classification of the REEs was into two main groups, videlicet cerium earth (Sc, La, Ce, Pr, Nd, and Sm) and yttrium earth (Y, Dy, Ho, Er, Tm,
$\mathrm{Yb}$, and $\mathrm{Lu})$. Europium, gadolinium, and terbium were either well-thought-of as a separate cluster (terbium group), or europium was included in the cerium group; and gadolinium and terbium were classified in the yttrium group. The reason for this separation came up from the difference in solubility of rare-earth double sulfates with sodium and potassium. The sodium double sulfates of the cerium group are difficultly soluble, those of the terbium group slightly, and those of the yttrium group are highly soluble [5]. Although the classification is inconsistent among the authors, the most common distinction of the REEs today is based on the atomic numbers, where those with low atomic numbers are grouped as the light REEs ( $\mathrm{La}, \mathrm{Ce}, \mathrm{Pr}, \mathrm{Nd}$ ); those with high atomic numbers are the heavy REEs (Ho, Er, Tm, $\mathrm{Yb}, \mathrm{Lu})$; and those that fall in between are exclusively referred to as the middle REEs (Pm, Sm, Eu, Gd, Tb, Dy) $[6,7]$. 
Over the past few decades, the use of rare earth elements either individually or in mixtures shows an increasing trend, where it is because these metals have the best characteristics for various fields of technology [8]. The REEs have wide applications in the hightechnology industries classified into some areas such as electronics: television screens, computers, cell phones; manufacturing: high strength magnets, metal alloys, stress gauges; technology: lasers, optical glass, fiber optics; renewable: hybrid automobiles, wind turbines, next-generation rechargeable batteries; and energy: biofuel catalysts [9, 10, 11]. Recently, the REEs have been being utilized in medical science, such as nano-biology and regenerative medicine $[12,13]$, magnetic resonance imaging (MRI) contrast agents [14, 15, 16, 17], and biosensors and immunosensors $[18,19]$. Owing to their wide applications, today, REEs are well-known as 21stcentury materials [20].

The REEs are a highly coherent group of elements, and their accurate determination is essential in chemistry research [21]. Analysis and separation of the REEs from their sample matrix or even analysis and isolation of one REE being a single element are difficult because these metals have similar properties, especially physical and chemical properties, and universally originate in the same mineral assemblies [22]. This hindrance must be overcome quickly because the high demand of the REEs increases steadily, either in amount or purity [23]. Although inductively coupled plasmaoptical emission spectrometry (ICP-OES) is quite good in determining the REEs $[24,25,26]$; however, it is timeconsuming and expensive. On the other hand, modern automatic analysis methods provide opportunities to collect large amounts of data very easily and are considered valuable and promising ones due to their fast, robustness, precise and less sensitivity to spectral artifacts, and cost-effectiveness [27]. Thus, developing an analysis method for the determination of the REEs based on the modern automatic analysis is desirable.

Developing an analysis method which not only concerns the effectiveness but the efficiency as well requires in-depth study. Although univariate analysis is still widely applied to construct calibration plots to determine the REEs, some drawbacks of this approach, such as less comprehensive and non-establish relationships towards different factors, cannot be denied [28]. On the other side, multivariate analysis is recently becoming the most expectant approach of calibration strategies because of its ability to permit matrix effects corrections. Multivariate analysis is generally used to study more complex sets of data than what univariate analysis can handle. Furthermore, multivariate analysis enables an ability to glean a more realistic picture than looking at a single variable. Multivariate techniques also provide a robust test of significance compared with univariate techniques [29]. In this study, we integrated the ultraviolet-visible (UV-vis) spectroscopic method and principal component regression (PCR) multivariate analysis to develop a robust analytical method to determine the middle REEs. In addition, it has been wellknown that the UV-vis spectroscopic can produce a large amount of data in a short time of analysis. The data could be extracted by employing multivariate analysis to generate valuable insights about the chemicals' content and noise. Therefore, a hybrid of the UV-vis spectroscopic and multivariate analysis would be an effective and efficient method for determining the middle REEs.

In the present study, a novel analysis method was developed to determine the middle REEs (samarium, europium, gadolinium, terbium, and dysprosium) in fast, simultaneous, and without chemical separation. The proposed method was constructed by combining UV-vis spectroscopic and PCR multivariate calibration. The performance of the developed method was discussed in terms of selectivity, accuracy and precision, detection limit, and real sample test. The reliability of the proposed method was evaluated using monazite samples by comparing the results obtained with the results from ICP-OES.

\section{Methodology}

\subsection{Equipment and Materials}

Experiments were carried out using chemicals of pure-, or reagent- or analytical grade, as required. The chemicals used in the experiments consisted of the middle rare-earth element oxides: samarium oxide $\left(\mathrm{Sm}_{2} \mathrm{O}_{3}\right)$, europium oxide $\left(\mathrm{Eu}_{2} \mathrm{O}_{3}\right)$, gadolinium oxide $\left(\mathrm{Gd}_{2} \mathrm{O}_{3}\right)$, terbium oxide $\left(\mathrm{Tb}_{2} \mathrm{O}_{3}\right)$, dan dysprosium oxide $\left(\mathrm{Dy}_{2} \mathrm{O}_{3}\right)$, ammonium iron(II) sulfate hexahydrate $\left(\left(\mathrm{NH}_{4}\right)_{2} \mathrm{Fe}\left(\mathrm{SO}_{4}\right)_{2} \cdot 6 \mathrm{H}_{2} \mathrm{O}\right)$, manganese(III) sulfate hydrate $\left(\mathrm{MnSO}_{4} \cdot \mathrm{H}_{2} \mathrm{O}\right)$, calcium carbonate $\left(\mathrm{CaCO}_{3}\right)$, sodium carbonate $\left(\mathrm{Na}_{2} \mathrm{CO}_{3}\right)$, and lead(II) nitrate $\left(\mathrm{Pb}\left(\mathrm{NO}_{3}\right)_{2}\right)$, nitric acid $\left(\mathrm{HNO}_{3}\right)(65 \%)$, sodium phosphate dibasic $\left(\mathrm{Na}_{2} \mathrm{HPO}_{4}\right) \geq 99 \%$, and sodium dihydrogen phosphate monohydrate $\left(\mathrm{NaH}_{2} \mathrm{PO}_{4} \cdot \mathrm{H}_{2} \mathrm{O}\right) \geq 98 \%$ were purchased from E. Merck and used as received. Monazite samples bearing the middle rare-earth elements were obtained from the National Nuclear Energy Agency/Badan Tenaga Nuklir Nasional (BATAN), Indonesia. The UV-vis data (variation of absorbance for each wavelength) were obtained with the ultraviolet-visible spectroscopic lambda 35 (Perkin Elmer). The multivariate data analysis was performed in the Rare Earth Element Study Center of Universitas Padjadjaran (Bandung) using the XLSTAT package program, which is well-known as a powerful yet flexible Excel data analysis add-on allows users to analyze, customize and share results within Microsoft Excel.

\subsection{Preparation of the Solutions}

Training set solutions were prepared based on the reported method [30]. Briefly, a certain amount of the middle REE oxides $\left(\mathrm{Sm}_{2} \mathrm{O}_{3}, \mathrm{Eu}_{2} \mathrm{O}_{3}, \mathrm{Gd}_{2} \mathrm{O}_{3}, \mathrm{~Tb}_{2} \mathrm{O}_{3}\right.$, and $\mathrm{Dy}_{2} \mathrm{O}_{3}$ ) was separately dissolved with concentrated nitric acid under gentle stirring and heating. After the middle REE oxides were utterly dissolved, distilled water was adjusted to prepare the proper concentration of the middle REE solutions. The training set solutions were prepared by diluting the previously prepared solutions with various concentrations of the middle REEs shown in Table 1. 
Table 1. Various concentrations of the middle REEs in the training set.

\begin{tabular}{|c|c|c|c|c|c|c|c|c|c|c|c|c|c|c|c|c|c|}
\hline \multirow{2}{*}{ TS } & \multicolumn{5}{|c|}{ Conc. of the REEs (ppm) } & \multirow{2}{*}{ TS } & \multicolumn{5}{|c|}{ Conc. of the REEs (ppm) } & \multirow{2}{*}{ TS } & \multicolumn{5}{|c|}{ Conc. of the REEs (ppm) } \\
\hline & $\mathrm{Sm}$ & $\mathrm{Eu}$ & Gd & $\mathrm{Tb}$ & Dy & & Sm & $\mathrm{Eu}$ & Gd & $\mathrm{Tb}$ & Dy & & $\mathrm{Sm}$ & $\mathrm{Eu}$ & Gd & $\mathrm{Tb}$ & Dy \\
\hline 1 & 170 & 25 & 200 & 30 & 215 & 12 & 170 & 47 & 2000 & 100 & 215 & 23 & 263 & 91 & 1640 & 86 & 323 \\
\hline 2 & 263 & 25 & 560 & 44 & 323 & 13 & 356 & 47 & 200 & 30 & 431 & 24 & 356 & 91 & 2000 & 100 & 431 \\
\hline 3 & 356 & 25 & 920 & 58 & 431 & 14 & 449 & 47 & 560 & 44 & 539 & 25 & 542 & 91 & 200 & 30 & 647 \\
\hline 4 & 449 & 25 & 1280 & 72 & 539 & 15 & 542 & 69 & 920 & 58 & 647 & 26 & 635 & 91 & 560 & 44 & 755 \\
\hline 5 & 542 & 25 & 1640 & 86 & 647 & 16 & 635 & 69 & 1280 & 72 & 755 & 27 & 356 & 113 & 1640 & 86 & 431 \\
\hline 6 & 635 & 25 & 2000 & 100 & 755 & 17 & 170 & 69 & 1640 & 86 & 215 & 28 & 449 & 113 & 2000 & 100 & 539 \\
\hline 7 & 263 & 25 & 200 & 30 & 323 & 18 & 263 & 69 & 2000 & 100 & 323 & 29 & 635 & 113 & 200 & 30 & 755 \\
\hline 8 & 356 & 47 & 560 & 44 & 431 & 19 & 449 & 69 & 200 & 30 & 539 & 30 & 170 & 113 & 560 & 44 & 215 \\
\hline 9 & 449 & 47 & 920 & 58 & 539 & 20 & 542 & 69 & 560 & 44 & 647 & 31 & 263 & 113 & 920 & 58 & 323 \\
\hline 10 & 542 & 47 & 1280 & 72 & 647 & 21 & 635 & 69 & 920 & 58 & 755 & 32 & 542 & 135 & 2000 & 100 & 647 \\
\hline 11 & 635 & 47 & 1640 & 86 & 755 & 22 & 170 & 91 & 1280 & 72 & 215 & 33 & 170 & 135 & 200 & 30 & 215 \\
\hline
\end{tabular}

${ }^{{ }^{*} \mathrm{TS}}=$ Training Set

Matrix solution was prepared by dissolving the compounds present in the real sample matrix, as reported by Manurung [31]. To do this, $0.992 \mathrm{~g}$ $\left(\mathrm{NH}_{4}\right)_{2} \mathrm{Fe}\left(\mathrm{SO}_{4}\right)_{2} .6 \mathrm{H}_{2} \mathrm{O}, 0.042 \mathrm{mg} \mathrm{MnSO}_{4} \cdot \mathrm{H}_{2} \mathrm{O}, 0.065 \mathrm{mg}$ $\mathrm{CaCO}_{3}, 0.085 \mathrm{mg} \mathrm{Na}_{2} \mathrm{CO}_{3}$, and $0.138 \mathrm{~g} \mathrm{~Pb}\left(\mathrm{NO}_{3}\right)_{2}$ were weighed and mixed. The mixture was calcined at $875^{\circ} \mathrm{C}$ for $30 \mathrm{~min}$, which was started at $80^{\circ} \mathrm{C}$ for $5 \mathrm{~min}$, and then the temperature was gradually increased to be 100,300 , and $500^{\circ} \mathrm{C}$ with the same length of time for each temperature. Next, the mixture was cooled in a desiccator. After that, the matrix mixture was dissolved with $10 \mathrm{ml}$ of $\mathrm{HNO}_{3} 65 \%$ and diluted with distilled water to be $1 \mathrm{~L}$.

Dissolution of monazite samples was prepared using the previously reported method [32]. At first, approximately $0.1 \mathrm{~g}$ of monazite sample was accurately weighed and homogeneously mixed with $\mathrm{Na}_{2} \mathrm{HPO}_{4} / \mathrm{NaH}_{2} \mathrm{PO}_{4} \cdot \mathrm{H}_{2} \mathrm{O}$ in a mass ratio of $1: 15$ sample: flux. The mixture was quantitatively transferred into a platinum crucible and heated at $900^{\circ} \mathrm{C}$ in a closed oven with a periodical swirling at $15 \mathrm{~min}$ intervals. Visual inspection of the sample indicated complete digestion after $60 \mathrm{~min}$. The resultant melt was cooled to room temperature and dissolved in $30 \mathrm{ml}$ of distilled water. The dissolved melt was quantitatively transferred to a $100.0 \mathrm{ml}$ volumetric flask and filled to the mark with distilled water.

\subsection{Ultraviolet-visible Spectroscopic Analysis}

All solutions were measured using ultravioletvisible spectroscopic lambda 35 at wavelength range 200-600 $\mathrm{nm}$ for interval $10 \mathrm{~nm}$.

\subsection{Multivariate Data Analysis}

The UV-vis data obtained were arranged to be a data matrix (absorbance variation for each wavelength). The data matrix was analyzed using principal component analysis (PCA) and principal component regression (PCR) multivariate calibration.

\section{Results and Discussion}

The proposed analysis method was constructed by combining ultraviolet-visible spectroscopic (UV-vis spectroscopic) and multivariate analysis. The ultraviolet-visible spectroscopic analysis generally requires a short analysis time with a resulting large amount of data due to no need to optimize the wavelength used in the experiments. The large amount of data obtained from a spectroscopic method is next extracted to generate meaningful information about the chemicals' content and noise. The illustration of the advanced analysis method is depicted in Figure 1.

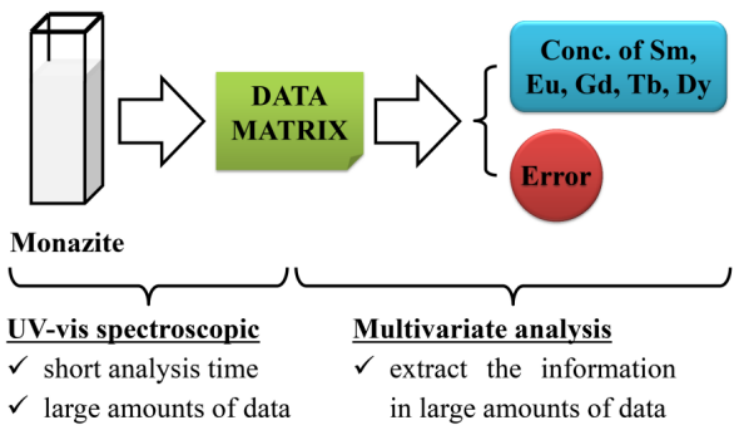

Figure 1. Schematic representation of the determination of the middle REEs by a combination of UV-vis and multivariate analysis.

\subsection{Ultraviolet-visible Spectroscopic Analysis}

The UV-vis absorption spectra of the middle REEs held a great deal of information despite their continuous and seemingly uninformative shape. They had an overlapping spectrum (shown in Figure 2), which informed that not possible determined by univariate analysis. Wiberg et al. [27] reported that the uninformative shape of UV-vis absorption spectra was possible with multivariate data analysis to obtain good results for both quantitative and qualitative determinations. 


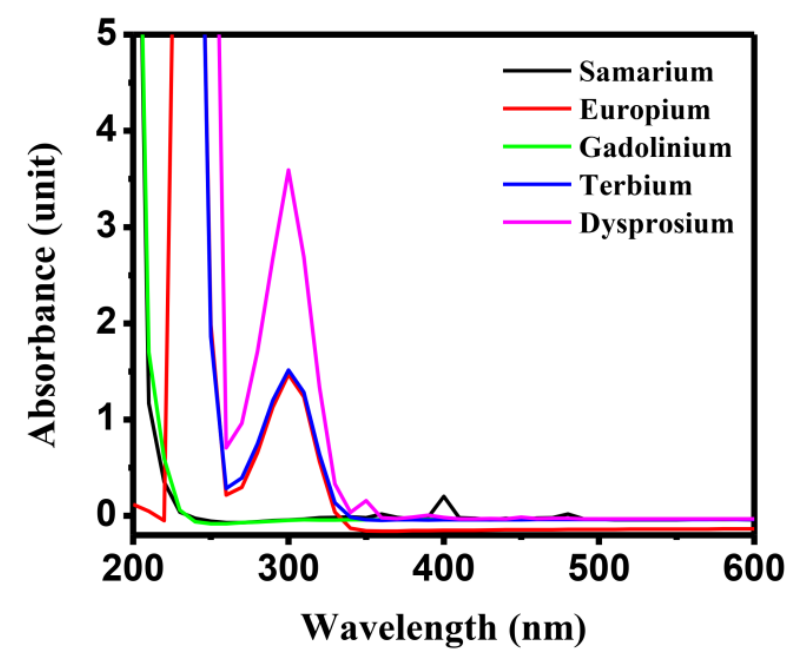

Figure 2. Two-dimension graphic of UV-vis absorption spectra of the middle REEs at wavelength range 200$600 \mathrm{~nm}$ for interval $10 \mathrm{~nm}$.

\subsection{Multivariate Data Analysis}

In establishing the mathematics model of PCR multivariate calibration, at first, the data matrix must be normalized to get a better mathematics model. The data matrix normalized will give a more robust mathematics model than that of not normalized, as mentioned by Brereton [33]. The reasons for performing data pretreatment are generally to reduce the effect of noise, improve the model's predictive ability, and simplify the model. In this study, normalization of the data matrix was conducted using row-scaling pre-processing. Next, the normalized data matrix was analyzed using PCA to get principal components (PCs), converted by PCR to be a concentration. According to Miller et al. [34], the score plot of the first two PCs is usually the most useful because these PCs describe the most significant variance in the data. The score plot describes the similarities and the different data properties in every sample (training set). Figure 2 (F) shows the score plot of the first two PCs obtained from the normalized data matrix. Simply, it explained that two training sets are laid far from others, corresponding to characteristic differences of the training sets (containing extremely high/low concentration of the REEs).

The PCR multivariate calibration was applied for establishing the mathematics model of the middle REEs. The coefficient of determination, R2, evaluated the goodness of the mathematics model and root mean square error calibration, RMSEC. The $R^{2}$ value for samarium, europium, gadolinium, terbium, and dysprosium was 1.000, 1.000, 0.993, 0.993, and 1.000, respectively, while the RSMEC value was 3.900, 0.819 , $310.832,12.088$, and 4.529 , respectively. Fu et al. [35] stated that evaluation of the predictive ability of a quantitative multivariate calibration model could be made employing the RMSE and $\mathrm{R}^{2}$, where the closer $\mathrm{R}^{2}$ is to unity, the better the linear model explains the $\mathrm{y}$ variations. Figure $3(\mathrm{~A}-\mathrm{E})$ and Table 2 showed predictive concentration of the middle REEs to actual concentration in the training set solutions. Those data indicated that the predictive concentration of the middle REEs was close to the actual concentration. Graphically, it could be seen from the distribution pattern of the data, centrally in one point. To confirm the mathematics model which was obtained from multivariate calibration if robust or not for the determination of the middle REEs, crossvalidation (CV) was employed. In this study, the $\mathrm{R}^{2}$ value of the CV for samarium, europium, gadolinium, terbium, and dysprosium was 1.000, 1.000, 1.000, 1.000, and 1.000 , respectively, while RSMEV value was $0.360,0.473$, $15.811,0.609$, and 0.390 , respectively.

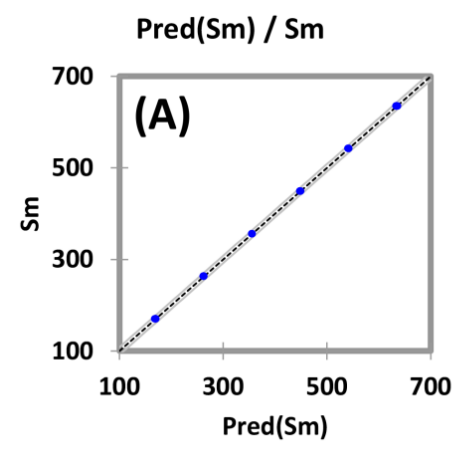

Pred(Eu) / Eu
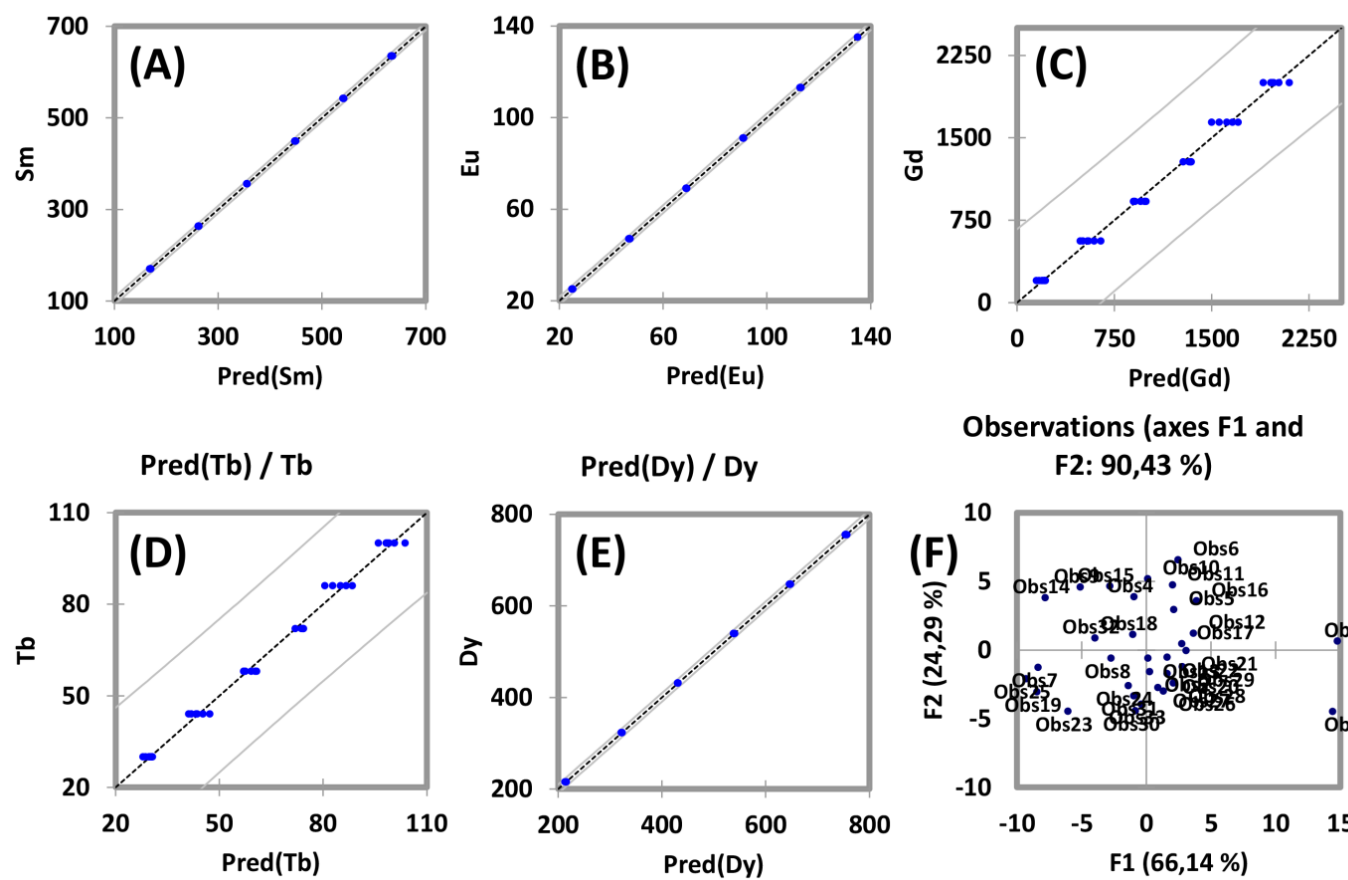

Observations (axes F1 and

F2: $90,43 \%$ )

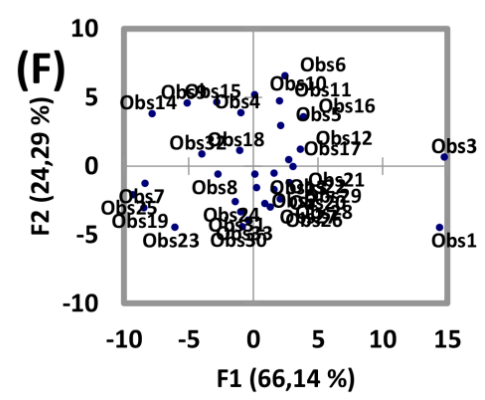

Figure 3. (A-E) Predictive concentration of the middle REEs to actual concentration. (F) Score plot of the first two PCs from absorbance. 
Table 2. The comparison of the predictive concentration of the middle REEs to actual concentration.

\begin{tabular}{|c|c|c|c|c|c|c|c|c|c|}
\hline $\mathrm{C}_{\mathrm{Sm}}$ & $\hat{\mathrm{C}}_{\mathrm{Sm}}$ & $\mathrm{C}_{\mathrm{Eu}}$ & $\hat{\mathrm{C}}_{\text {हu }}$ & $\mathrm{C}_{\mathrm{Gd}}$ & $\hat{\mathrm{C}}_{\mathrm{Gd}}$ & $\mathrm{C}_{\mathrm{Tb}}$ & $\hat{\mathrm{C}}_{\mathrm{Tb}}$ & $\mathrm{C}_{\mathrm{Dy}}$ & $\hat{\mathrm{C}}_{\mathrm{Dy}}$ \\
\hline 170 & $170.054( \pm 0.755)$ & 25 & $25.021( \pm 0.121)$ & 200 & $149.354( \pm 25.524)$ & 30 & $29.742( \pm 0.993)$ & 215 & $215.062( \pm 0.877)$ \\
\hline 263 & $262.815( \pm 0.655)$ & 47 & $47.001( \pm 0.208)$ & 560 & $555.629( \pm 57.476)$ & 44 & $43.830( \pm 2.235)$ & 323 & $322.785( \pm 0.760)$ \\
\hline 356 & $356.018( \pm 0.436)$ & 69 & $68.980( \pm 0.107)$ & 920 & $948.036( \pm 43.398)$ & 58 & $59.090( \pm 1.688)$ & 431 & $431.021( \pm 0.506)$ \\
\hline 449 & $449.072( \pm 0.746)$ & 91 & $90.947( \pm 0.138)$ & 1280 & $1322.626( \pm 28.233)$ & 72 & $73.658( \pm 1.098)$ & 539 & $539.084( \pm 0.867)$ \\
\hline 542 & $542.210( \pm 0.589)$ & 113 & $113.042( \pm 0.186)$ & 1640 & $1608.870( \pm 80.754)$ & 86 & $84.789( \pm 3.140)$ & 647 & $647.244( \pm 0.684)$ \\
\hline 635 & $634.815( \pm 1.023)$ & 135 & $135.019( \pm 0.098)$ & 2000 & $1986.286( \pm 67.207)$ & 100 & $99.467( \pm 2.614)$ & 755 & $754.785( \pm 1.188)$ \\
\hline
\end{tabular}

${ }^{*} \mathrm{C}=$ Actual concentration (ppm) and

${ }^{*} \hat{\mathrm{C}}=$ Predictive concentration $(\mathrm{ppm})$

3.3. Performance of the Developed Method, Selectivity, Accuracy, and Precision

The predictive concentration of the middle REEs was evaluated by t-test to investigate the accuracy of the developed method. The results showed that the computed $\mathrm{p}$-value was greater than the significance level alpha $=0.05$, which means no significant difference between means of reference and predictive REEs at the 5 $\%$ level. Therefore, the developed method has good accuracy. Konieczka and Namiesnik [36] defined accuracy as the closeness of agreement between a measured quantity value and a valid quantity value of a measurement. In addition, the accuracy also could be determined from RMSE, as discussed previously. The precision was evaluated from standard deviation (SD) (shown in Table 2), where the lower value of standard deviation, the higher level of precision.

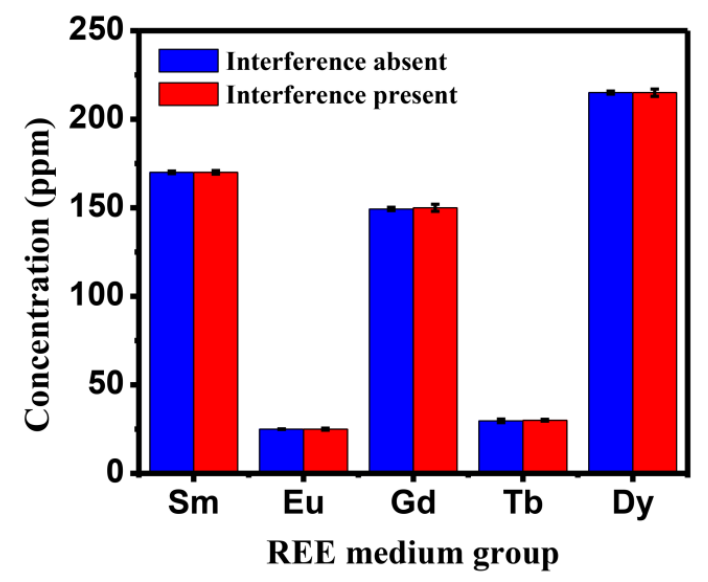

Figure 4. The predictive concentration of the middle REEs without interfering compounds (blue bar) and with interfering compounds (red bar).

The selectivity of the developed method was demonstrated by testing the compounds that were present in the real sample matrix, such as ammonium iron(II) sulfate hexahydrate $\left(\mathrm{NH}_{4}\right)_{2} \mathrm{Fe}\left(\mathrm{SO}_{4}\right)_{2} \cdot 6 \mathrm{H}_{2} \mathrm{O}$, manganese(III) sulfate hydrate $\left(\mathrm{MnSO}_{4} \cdot \mathrm{H}_{2} \mathrm{O}\right)$, calcium carbonate $\left(\mathrm{CaCO}_{3}\right)$, sodium carbonate $\left(\mathrm{Na}_{2} \mathrm{CO}_{3}\right)$, and
lead(II) nitrate $\left(\mathrm{Pb}\left(\mathrm{NO}_{3}\right)_{2}\right)$ with a concentration of 2.29 , $0.0965,0.15,0.195$, and $0.32 \%$, respectively. The results showed that the developed method giving a satisfactory result of the selectivity test, where the interference compounds did not significantly affect the predictive concentration of the middle REEs obtained. Figure 4 shows a relative concentration of the middle REEs with the presence and absence of the interference compounds. This indicated that the proposed method is highly selective and has no interference from other compounds.

The detection limit of the proposed method was determined by a statistical approach based on measuring replicate blank samples. Using the following equations [37]:

$$
\begin{aligned}
& \text { LoD }=\text { LoB }+1.645 \text { (SDlow conc. sample) } \\
& \mathrm{LoB}=\text { mean blank }+1.645\left(\mathrm{SD}_{\text {blank }}\right)
\end{aligned}
$$

where LoD and LoB refer to limit of detection and limit of blank; the detection limit obtained for samarium, europium, gadolinium, terbium, and dysprosium was 1.375 ( \pm 0.012$), 0.332( \pm 0.0041), 42.117( \pm 0.20), 1.767( \pm$ $0.011)$, and $0.576( \pm 0.002) \mathrm{ppm}$, respectively.

\subsection{Real Sample Analysis}

The proposed method's reliability was examined by the determination of the middle REEs in the monazite samples, which were obtained from the National Nuclear Energy Agency/Badan Tenaga Nuklir Nasional (BATAN) in Indonesia. The concentration of the middle REEs in the monazite samples was determined using the proposed method, and the results were compared with the results obtained from ICP-OES (shown in Table 3). The data were then evaluated using a two-sample t-test with a $95 \%$ confidence level $(n=10)$. The results showed that the calculated $t$ value $(-0.44,0.55,0.98,-0.41,1.21$, respectively for $\mathrm{Sm}, \mathrm{Eu}, \mathrm{Gd}, \mathrm{Tb}, \mathrm{Dy}$ ) lay on between the positive and negative critical $t$ value $(-2.31 / 2.31)$, indicating there is no significant difference between means of concentration of the middle REEs in the monazite samples obtained using the developed method and the results obtained from ICP-OES. 
Table 3. The result comparison between the proposed method and the ICP-OES for the middle REEs in monazite samples.

\begin{tabular}{ccccccccccc}
\hline Sample & \multicolumn{9}{c}{ The proposed method $(\mathrm{ppm})$} & \multicolumn{5}{c}{ ICP-OES (ppm) } \\
\cline { 2 - 11 } & $\mathrm{Sm}$ & $\mathrm{Eu}$ & $\mathrm{Gd}$ & $\mathrm{Tb}$ & $\mathrm{Dy}$ & $\mathrm{Sm}$ & $\mathrm{Eu}$ & $\mathrm{Gd}$ & $\mathrm{Tb}$ & $\mathrm{Dy}$ \\
\hline 1 & 400.252 & 81.773 & 1125.011 & 64.551 & 490.117 & 402.321 & 80.764 & 1100.227 & 65.980 & 485.079 \\
& $( \pm 4.323)$ & $( \pm 0.574)$ & $( \pm 5.552)$ & $( \pm 3.132)$ & $( \pm 5.037)$ & $( \pm 7.432)$ & $( \pm 1.324)$ & $( \pm 2.916)$ & $( \pm 8.019)$ & $( \pm 8.818)$ \\
2 & 399.513 & 83.435 & 1120.910 & 63.513 & 489.796 & 400.013 & 82.315 & 1121.074 & 63.117 & 489.667 \\
& $( \pm 5.138)$ & $( \pm 0.675)$ & $( \pm 6.090)$ & $( \pm 3.133)$ & $( \pm 4.137)$ & $( \pm 2.104)$ & $( \pm 1.705)$ & $( \pm 4.653)$ & $( \pm 3.137)$ & $( \pm 6.787)$ \\
3 & 400.011 & 82.093 & 1127.008 & 64.022 & 491.014 & 400.145 & 82.196 & 1126.503 & 63.527 & 481.196 \\
& $( \pm 3.982)$ & $( \pm 0.773)$ & $( \pm 3.008)$ & $( \pm 3.133)$ & $( \pm 3.304)$ & $( \pm 3.006)$ & $( \pm 2.006)$ & $( \pm 4.602)$ & $( \pm 3.136)$ & $( \pm 5.756)$ \\
4 & 402.118 & 79.172 & 1126.028 & 62.962 & 492.003 & 401.011 & 78.109 & 1127.136 & 63.165 & 484.100 \\
& $( \pm 7.438)$ & $( \pm 0.131)$ & $( \pm 4.217)$ & $( \pm 3.135)$ & $( \pm 2.932)$ & $( \pm 0.931)$ & $( \pm 4.038)$ & $( \pm 6.918)$ & $( \pm 3.134)$ & $( \pm 6.906)$ \\
5 & 397.099 & 77.972 & 1126.216 & 62.219 & 488.990 & 397.893 & 76.998 & 1124.996 & 62.914 & 484.145 \\
& $( \pm 6.081)$ & $( \pm 0.992)$ & $( \pm 6.157)$ & $( \pm 3.130)$ & $( \pm 5.419)$ & $( \pm 7.084)$ & $( \pm 1.967)$ & $( \pm 7.595)$ & $( \pm 3.133)$ & $( \pm 2.746)$ \\
\hline
\end{tabular}

\section{Conclusions}

A speedy and selective analysis method has been successfully developed to determine the middle REEs in the monazite samples. The proposed analysis method was indeed selectively proven by determining the middle REEs in the presence of other chemical compounds, easy and fast because the proposed method did not require chemical separations since the data obtained were analyzed by multivariate analysis. The detection limit of the proposed method for $\mathrm{Sm}, \mathrm{Eu}, \mathrm{Gd}, \mathrm{Tb}$, and $\mathrm{Dy}$ was 1.375 ( \pm 0.012$), 0.332( \pm 0.004), 42.117( \pm 0.200), 1.767( \pm$ $0.011)$, and $0.576( \pm 0.002) \mathrm{ppm}$, respectively. The advanced analysis method was successfully applied to determine the middle REEs in monazite samples and is next expected to be utilized for routine quality control activity of the rare-earth element production.

\section{Acknowledgments}

This investigation was financially supported by Academic Leadership Grant (ALG) (No. 1427/UN6.3.1/LT/2020). We thank Kansi Haikal, S.Si. and Susianti, S.Si. in the Central Laboratory of Universitas Padjadjaran for UV-vis Spectroscopy and ICP-OES measurements, Rizki M. Cedia Sari, S.Si. in the Departement of Chemistry, Faculty of Mathematics and Natural Sciences, Universitas Padjadjaran for instruments' calibration, and the Rare Earth Element Study Center of Universitas Padjadjaran (Bandung) for providing permission to use XLSTAT package program.

\section{References}

[1] Husein H. Bahti, Yayah Mulyasih, Anni Anggraeni, Extraction and chromatographic studies on rareearth elements (REEs) from their minerals: the prospect of REEs production in Indonesia, Proceedings of the 2nd International Seminar on Chemistry, 2011

[2] Michael T. Aide, Christine Aide, Rare Earth Elements: Their Importance in Understanding Soil Genesis, ISRN Soil Science, 2012, (2012), 783876 https://doi.org/10.5402/2012/783876

[3] V. Balaram, V. K. Banakar, K. S. V. Subramanyam, Parijat Roy, M. Satyanarayanan, M. Ram Mohan, S. S. Sawant, Yttrium and rare earth element contents in seamount cobalt crusts in the Indian Ocean, Current Science, 103, 11, (2012), 1334-1338

[4] Beata Zawisza, Katarzyna Pytlakowska, Barbara Feist, Marzena Polowniak, Andrzej Kita, Rafal Sitko,
Determination of rare earth elements by spectroscopic techniques: a review, Journal of Analytical Atomic Spectrometry, 26, 12, (2011), 23732390 http://dx.doi.org/10.1039/C1JA10140D

[5] B. Smith Hopkins, Chemistry of the Rarer Elements, D.C. Heath, 1923

[6] Na Sui, Kun Huang, Chao Zhang, Ning Wang, Fuchun Wang, Huizhou Liu, Light, Middle, and Heavy Rare-Earth Group Separation: A New Approach via a Liquid-Liquid-Liquid Three-Phase System, Industrial \& Engineering Chemistry Research, 52, 17, (2013), 5997-6008 https://doi.org/10.1021/ie4002553

[7] D. W. Shin, J. G. Kim, Study On The Separation And Extraction Of Rare-Earth Elements From The Phosphor Recovered From End Of Life Fluorescent Lamps, Archives of Metallurgy and Materials, 60, 2, (2015), 1257-1260

https://doi.org/10.1515/amm-2015-0109

[8] Anni Anggraeni, Fernando Arianto, Abdul Mutalib, Uji Pratomo, Husein H. Bahti, Fast and simultaneously determination of light and heavy rare earth elements in monazite using combination of ultraviolet-visible spectrophotometry and multivariate analysis, AIP Conference Proceedings, $1848,1,(2017), 030004$

https://doi.org/10.1063/1.4983936

[9] C. A. Morais, V. S. T. Ciminelli, Process development for the recovery of high-grade lanthanum by solvent extraction, Hydrometallurgy, 73, 3, (2004), 237-244

https://doi.org/10.1016/j.hydromet.2003.10.008

[10] V. Balaram, Recent trends in the instrumental analysis of rare earth elements in geological and industrial materials, TrAC Trends in Analytical Chemistry, 15, 9, (1996), 475-486 https://doi.org/10.1016/S0165-9936(96)00058-1

[11] V. Balaram, Rare earth elements: A review of applications, occurrence, exploration, analysis, recycling, and environmental impact, Geoscience Frontiers, 10, 4, (2019), 1285-1303 https://doi.org/10.1016/j.gsf.2018.12.005

[12] Jessica T. Dahle, Yuji Arai, Environmental Geochemistry of Cerium: Applications and Toxicology of Cerium Oxide Nanoparticles, International Journal of Environmental Research and Public Health, 12, 2, (2015), 1253-1278 https://doi.org/10.3390/ijerph120201253 
[13] Bryant C. Nelson, Monique E. Johnson, Marlon L. Walker, Kathryn R. Riley, Christopher M. Sims, Antioxidant Cerium Oxide Nanoparticles in Biology and Medicine, Antioxidants, 5, 2, (2016), 15 https://doi.org/10.3390/antiox5020015

[14] Diana Rakhmawaty Eddy, Anni Anggraeni, RETNA PUTRI FAUzIA, Iman Rahayu, Abdul Mutalib, M Lutfi Firdaus, Husein Hernandi Bahti, GadoliniumMesoporous Silica as a Potential Magnetic Resonance Imaging Contrast Agents, Oriental Journal of Chemistry, 34, 5, (2018), 2603-2607 http://dx.doi.org/10.13005/ojc/340550

[15] Hardiani Rahmania, Abdul Mutalib, Martalena Ramli, Jutti Levita, Synthesis and stability test of radiogadolinium(III)-DOTA-PAMAM G3.0trastuzumab as SPECT-MRI molecular imaging agent for diagnosis of HER-2 positive breast cancer, Journal of Radiation Research and Applied Sciences, 8, 1, (2015), 91-99 https://doi.org/10.1016/j.jrras.2014.12.001

[16] Elke Debroye, Svetlana V. Eliseeva, Sophie Laurent, Luce Vander Elst, Stéphane Petoud, Robert N. Muller, Tatjana N. Parac-Vogt, Lanthanide(III) Complexes of Diethylenetriaminepentaacetic Acid (DTPA)-Bisamide Derivatives as Potential Agents for Bimodal (Optical/Magnetic Resonance) Imaging, European Journal of Inorganic Chemistry, 2013, 14, (2013), 2629-2639

https://doi.org/10.1002/ejic.201300196

[17] L. Vander Elst, S. Zhang, A. D. Sherry, S. Laurent, F. Botteman, R. N. Muller, Dy-Complexes as High Field T2 Contrast Agents: Influence of Water Exchange Rates, Academic Radiology, 9, 2, Supplement, (2002), S297-S299

https://doi.org/10.1016/S1076-6332(03)80208-8

[18] Fahimeh Charbgoo, Mansor Bin Ahmad, Majid Darroudi, Cerium oxide nanoparticles: green synthesis and biological applications, International Journal of Nanomedicine, 12, (2017), 1401-1413 https://doi.org/10.2147/IJN.S124855

[19] Yeni Wahyuni Hartati, Leonard Kristofel Letelay, Shabarni Gaffar, Santhy Wyantuti, Husein H. Bahti, Cerium oxide-monoclonal antibody bioconjugate for electrochemical immunosensing of HER2 as a breast cancer biomarker, Sensing and Bio-Sensing Research, 27, (2020), 100316

https://doi.org/10.1016/j.sbsr.2019.100316

[20] Liang Pei, Liming Wang, Xinglong Fu, Separation of Eu3+ Using a Novel Dispersion Combined Liquid Membrane with $\mathrm{P}_{507}$ in Kerosene as the Carrier, Chinese Journal of Chemical Engineering, 19, 1, (2011), 33-39 https://doi.org/10.1016/S1004-9541(09)60173-7

[21] Ehsan Zolfonoun, Seyed Reza Yousefi, Simultaneous determination of rare earth elements by ICP OES after on-Line enrichment using multiwalled carbon nanotubes coated cellulose acetate membrane, Journal of the Brazilian Chemical Society, 27, 12, (2016), 2348-2353

https://doi.org/10.5935/0103-5053.20160131

[22] Archana Kumari, Rekha Panda, Manis Kumar Jha, J. Rajesh Kumar, Jin Young Lee, Process development to recover rare earth metals from monazite mineral: A review, Minerals Engineering, 79, (2015), 102-115 https://doi.org/10.1016/j.mineng.2015.05.003
[23] Gordon Haxel, J.B. Hedrick, G.J. Orris, Rare Earth Elements: Critical Resources for High Technology, U.S. Department of the Interior, U.S. Geological Survey, 2002

[24] Jussiane Souza Silva, Alessandra Schneider Henn, Valderi Luiz Dressler, Paola Azevedo Mello, Erico Marlon Moraes Flores, Feasibility of Rare Earth Element Determination in Low Concentration in Crude Oil: Direct Sampling Electrothermal Vaporization-Inductively Coupled Plasma Mass Spectrometry, Analytical Chemistry, 90, 11, (2018), 7064-7071 https://doi.org/10.1021/acs.analchem.8b01460

[25] M. N. Rimskaya-Korsakova, A. V. Dubinin, V. M. Ivanov, Determination of Rare-Earth Elements in Sulfide Minerals by Inductively Coupled Plasma Mass Spectrometry with Ion-Exchange Preconcentration, Journal of Analytical Chemistry, 58, 9, (2003), 870-874 https://doi.org/10.1023/A:1025693302964

[26] K. Kawabata, Y. Kishi, O. Kawaguchi, Y. Watanabe, Y. Inoue, Determination of rare-earth elements by inductively coupled plasma mass spectrometry with ion chromatography, Analytical Chemistry, 63, 19, (1991), 2137-2140 https://doi.org/10.1021/ac00019a013

[27] Kent Wiberg, Anders Hagman, Peter Burén, Sven P. Jacobsson, Determination of the content and identity of lidocaine solutions with UV-visible spectroscopy and multivariate calibration, Analyst, 126, 7, (2001), 1142-1148 https://doi.org/10.1039/B102545G

[28] Sven Sindern, Analysis of Rare Earth Elements in Rock and Mineral Samples by ICP-MS and LA-ICPMS, Physical Sciences Reviews, 2, 2, (2017), 20160066 https://doi.org/10.1515/psr-2016-0066

[29] Jeyne Pricylla Castro, Diego Victor Babos, Edenir Rodrigues Pereira-Filho, Calibration strategies for the direct determination of rare earth elements in hard disk magnets using laser-induced breakdown spectroscopy, Talanta, 208, (2020), 120443 https://doi.org/10.1016/j.talanta.2019.120443

[30] A. Mutalib, H.H. Bahti, S.S. Pada, A rapid, simultaneous and efficient determination of Light and medium rare earth element in artificial matrix using combination of multivariate analysis and high performance liquid chromatography-diode array detecto, Seminar Nasional Universitas Pendidikan Indonesia, Bandung, 2016

[31] Anna Rohani Roida Manurung, Pengayaan Unsur Tanah Jarang Secara Destruksi dan Pengendapan dari Pasir Monasit Bangka, undergraduate thesis, Departement of Chemistry, IPB University, Bogor, 2013

[32] S. M. Xaba, M. Nete, W. Purcell, Concentration of rare earth elements from monazite by selective precipitation, IOP Conference Series: Materials Science and Engineering, 430, (2018), 012006 https://doi.org/10.1088/1757-899X/430/1/012006

[33] Richard G. Brereton, Chemometrics: Data Analysis for the Laboratory and Chemical Plant, John Wiley \& Sons, 2003

[34] James N. Miller, Jane Charlotte Miller, Robert D. Miller, Statistics and Chemometrics for Analytical Chemistry, Pearson Education Limited, 2017 
[35] Yang Fu, Haicheng Zhang, Wenjie Dong, Wenping Yuan, Comparison of Phenology Models for Predicting the Onset of Growing Season over the Northern Hemisphere, PLOS ONE, 9, 10, (2014), e109544

https://doi.org/10.1371/journal.pone.0109544

[36] Piotr Konieczka, Jacek Namiesnik, Quality Assurance and Quality Control in the Analytical Chemical Laboratory: A Practical Approach, CRC Press, 2009

[37] David A. Armbruster, Terry Pry, Limit of blank, limit of detection and limit of quantitation, The Clinical Biochemist Reviews, 29, Suppl 1, (2008), S49S52 